\title{
HR-RELATED ENTREPRENEURSHIP CHALLENGES FACED BY FOOD SECTOR COMPANIES
}

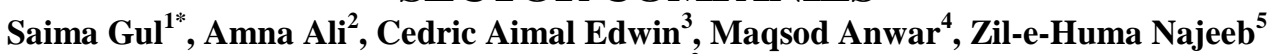 \\ ${ }^{1 *}, 5$ Ph.D., Scholar, Iqra National University Peshawar, Pakistan; ${ }^{2}$ Associate Professor, Iqra National University, Pakistan; \\ ${ }^{3}$ Assistant Professor/HoD, Management Sciences, CECOS University Peshawar, Pakistan; ${ }^{4}$ Reporting Officer, Provincial \\ Disaster Management Authority, KP, Pakistan. \\ Email: ${ }^{1 *}$ saima.gul83@gmail.com, ${ }^{2}$ am_pk97@yahoo.com, ${ }^{3}$ cedric@ @ cecos.edu.pk, ${ }_{5}^{4}$ maqsodanwar07@gmail.com, \\ 5il_humaafridi@yahoo.com
}

Article History: Received on $15^{\text {th }}$ June 2021, Revised on $27^{\text {th }}$ June 2021, Published on $30^{\text {th }}$ June 2021

\begin{abstract}
Purpose of the study: This study examines the key Human resource-related entrepreneurship challenges that the food companies face.

Methodology: The research approach utilized in this study was exploratory. The sampling size consists of 200 individuals. Four hypotheses were tested based on the four core challenges being faced by HR. Each hypothesis was calculated and weighed separately utilizing regression analysis.

Main Findings: The results obtained indicate that human resource management of the food sector companies needs to thoroughly plan the business so that it majorly focuses on its staff management as they are truly dependent on them for their profits and revenues. Thus, being the major drivers of success, management should invest a good amount in their training, knowledge, and learning.
\end{abstract}

Applications of this study: The findings can be helpful for a manager they can focus on the management of their staff for-profit and revenues.

Novelty/Originality of this study: The use of theory in this research paper is grounded theory and human resource management theory to present the findings on the human resource ground management forum.

Keywords: Entrepreneurship, HR, Management, Training, Knowledge, Food Sector, Profit, Learning.

\section{INTRODUCTION}

Human Resource Management is an integral part of an organization's success and growth. Efficient HR practices include practices of those attitudes and behaviors that result in a sustainable, consistent and work-friendly environment that provides the company with a competitive edge over market rivals. However, the HRM of an organization meets challenges every day that need an immediate solution for uninterrupted progress. Human resources (HR) related challenges issues affect all employers. However, due to the company's size, limited financial resources, and a smaller pool of human capital, these challenges can be more difficult for small businesses. As a result, effective human resource management is critical in today's more competitive business climate. Even businesses that have a strong understanding of human resource management face HR-related issues (Khanal, 2019; Lajqi, \& Krasniqi, 2017). The food and beverage sector also needs to accommodate the needs and ensure practices that increase their demand. This includes several factors including the advancement of knowledge and skills in their staff and to orient themselves with such attitude that fits the customers' demand. Day-to-day policymaking and its practice all over the organization is also one of the key encounters that management faces (British Columbia Cook Articulation Committee, 2018). HR involves a wide range of responsibilities, from assuring compliance with employment regulations to supervising and executing recruitment, training, and benefit programs (Akinbami, Olawoye, Adesina, \& Nelson, 2019; Welsh, Dragusin, \& Grosu, 2019).

Effective human resource management, including attempts to overcome typical HR challenges, is critical because it raises the possibility of your firm recruiting and maintaining actual assets that may propel your company forward. Furthermore, it lowers the risk of noncompliance with laws and regulations, ensuring that your personnel is effectively trained to do their tasks, and guarantees that workplace problems are addressed quickly and properly. Collaborative efforts bring more success, but it requires a better understanding of what the organization demands or aims to achieve from the workers' perspective. On the other side, the management demands proficient and resourceful work output that can only be achieved through appreciative and supportive communication and interaction. With the flourishing market, the competition is for real. Thus there's a need to recruit the talent pool also have become challenging. Human resource training and development (T\&D) in the food sector is crucial for building a capable and skilled workforce with the competence to face current and future challenges by providing them with technological skills and critical thinking abilities. The need for the administration of policies that can attract suitable applicants can only be possible if they are given the true rewards, appraisals, and appreciation they deserve that make them work harder for the company's vision (Benfield et al., 2018)

\section{Research Aim}

This study aims to examine those key Human resource-related entrepreneurship challenges by the food companies. 
Research Objective: The objective of this study includes-

- To appraise the effect of Extensive training and skill development of the workers by the HR professionals.

- To study written policy development by HR as a challenge.

- To investigate the importance of induction of interaction between the management and workforce by HR.

- To study the role of inclusion of incentives and appraisals for the employees by HR.

\section{LITERATURE REVIEW}

\section{Extensive training by HR professionals is an entrepreneurship challenge faced by the food sector companies}

The key fundamental issues that the HRM faces are regarding the workforce of the company. This includes the inability to perform at the company's demand scale due to a lack of skill and development in the working domain. Organizations today are facing issues with their employees' intellectual and creative capabilities that may slow down the pace of the company's growth graph. The problems come in two ways, including the educational requirement and skill limitation.HR faces this problem during the recruitment drives to find out the best person for their use. The problem is specific to this part and extends when the existing workers are not updated or able to use the latest technology or products the company has introduced for its betterment. Therefore, HR needs to introduce learning and training programs for the employees to help them make more use of their knowledge, skills, creativity, and behaviors. They should focus more on personal hygiene habits, avoid wastage, make the best possible use of the food material provided, and satisfy customers' demands. HR thus needs to orient extensive training programs, so the workforce is accommodated with the latest technology the food industry is utilizing (British Columbia Cook Articulation Committee, 2018; Abdullah, 2009)

\section{Written policy development by HR is an entrepreneurship challenge faced by the food sector companies}

Regarding the policy development and practice inside the organization, Human Resources needs to focus on several factors. This is one of the very crucial factors around which the growth and prosperity of a company revolve. The food sector companies are highly affected by employer engagement and their attitude towards work and their organization. The HR of the food industry faces challenges in terms of work culture, pays and wages, training and development, working hours, legal issues, and demands by the company. The factor that is closely associated with the food sector is minimum wage and more duty hours. The base salaries are mostly not up to a livable status. Thus the compensation criteria are one of the very important domains that need an eye of human resources. Salary inequity is another challenge faced by the newcomers in the food sector that too needs a solution from the HR department (Bradley et al., 2017). Compensation strategy should be made as per the workforce and business market based on top-level, mid-level, lowlevel. Besides, the proper set of rules and regulations in the form of an employee book should be provided to every worker to avoid any issues of indiscipline or disruptiveness (British Columbia Cook Articulation Committee, 2018; Bratton \& Gold, 2017).

\section{Induction of interaction by HR is an entrepreneurship challenge faced by the food sector companies}

The food and beverage sector is more dependent on the workforce than any other industrial sector. It has a direct relationship with the company's sales and profits as they drive the growth and popularity of the organization. Human resource needs to ensure that the workers and the management have been provided the time to discuss their thoughts, ideas, and opinions regarding the workplace. Therefore, the prime challenge and goal at the same human resource faces are workforce contented and driving behaviors. This motivation comes out and becomes operational when given a right check on their abilities by the management (Stewart \& Brown, 2019). The co-operation and collaboration on the managerial and working-level minimizes the gap of knowledge, expertise, and intellect skills and opens the door to better opportunities for the company and workers.HR needs to practice those policies that create a friendly work association between the management and employees. Besides, it also needs to practice a proper protocol regarding decision making, and participation in the company is equally valued and appreciated. The management shouldn't hand over their tasks to the subordinates (Bratton \& Gold, 2017).

\section{The inclusion of incentives by HR is an entrepreneurship challenge faced by the food sector companies}

Appreciation and acknowledgment bring a sense of loyalty and hard work, intending to serve better. Human Resource needs to focus on the appraisal and reward system for their employees by managing salary, benefit plans, and additional facilities. This also includes non-cash incentives, including services like health insurance, travel off, and others. The employees are the true drivers of huge revenue and profits in the food industry directly. Thus the better they will bring more customers (Stewart \& Brown, 2019). The appraisal and rewards in the food industry also involve the promotion of an individual to a higher rank that brings a sense of more responsibility and motivation. The core values of the food sector depend on "people principles" and "social responsibility." Provision of advantages and bonuses makes the workers feel a part of the organization where their thoughts and ideas are acknowledged and given due respect. Additionally, the employees should be provided with the salary they deserve following the amount of hard work and effort they put into the company's success (Bratton \& Gold, 2017). 


\section{Theoretical Framework}

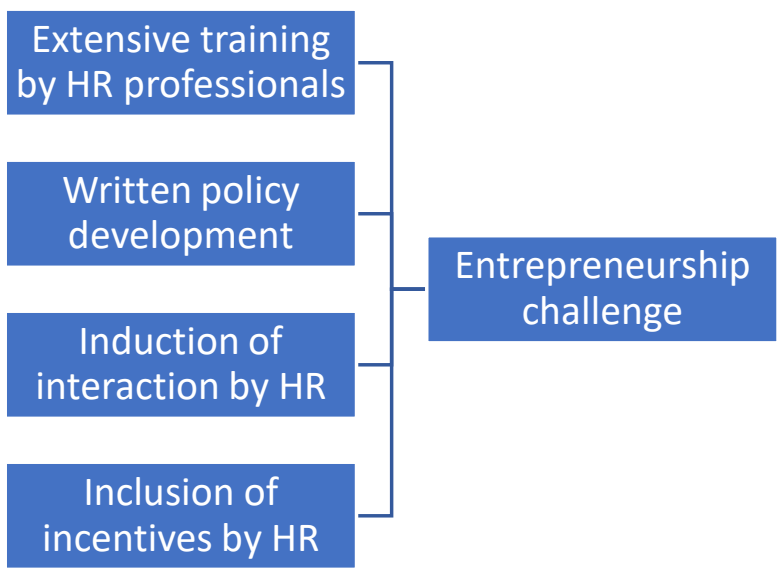

Figure 1: Conceptual framework

Source: Author analysis

The use of a theory that is done in this research paper is grounded theory and human resource management theory to present the findings on the human resource ground management forum.

Based on the literature review, the following hypotheses are drawn in the current study.

H1: Extensive training by HR professionals is an entrepreneurship challenge faced by the food sector companies.

H2: Written policy development by HR is an entrepreneurship challenge faced by the food sector companies.

H3: Induction of interaction by HR is an entrepreneurship challenge faced by the food sector companies.

H4: Inclusion of incentives by HR is an entrepreneurship challenge faced by the food sector companies.

\section{METHODOLOGY}

\section{Research approach}

The research approach utilized in this study is exploratory. This approach is usually applied where the problem is not mentioned or identified and is figured out through a general idea that can be used to detect the issues that can be considered for future research. Our research study also has identified some key challenges that are faced by Human Resource Management that can be further used for future researches to be carried on. A questionnaire was used as a primary research method.

\section{Research strategy}

The research strategy determines how the research has been designed to be conducted from planning to implementation and collecting and examining data. This study used the deductive approach as its main research strategy as this study depends on the previous research and scientific work being done previously. The deductive strategy makes use of the related theory and then tests its inference with the gathered data. Thus, the research strategy of this study focuses on the existing theories on human resource management and has deduced all the hypotheses from the previous studies done.

\section{Data Collection}

Data collection is the process of observing, collecting, calculating, and obtaining information through authentic methods. Qualitative research has several ways to collect data, including observations, audio or video analysis, and interviews.

This study used a questionnaire as a data collection tool. The questionnaire had questions regarding the challenges faced by Human resources of the food sector companies. Each question had four options regarding the challenge faced. Those who participated in the study are asked to choose the best option that fits their organization.

\section{Sampling Technique and Size}

Sampling in research is done to select those individuals out of a big population to make statistical interpretation and use it as a common characteristic displayed by the whole population. This research used the purposive sampling technique, also known as non-probability sampling, in which participants are chosen based on the researcher's ideas, beliefs, and thought patterns. This study using purposive sampling determined the key challenges human resources face in the food sector companies.

The sampling size consists of 200 individuals. Four hypotheses were tested based on the four core challenges being faced by HR. Each hypothesis was calculated and weighed separately utilizing regression analysis. 


\section{RESULTS}

The results concerning the hypotheses can be found below:

\section{Hypothesis \#1}

H1: Extensive training by HR professionals is an entrepreneurship challenge faced by the food sector companies.

Table 1: Model Summary

\begin{tabular}{lccccc}
\hline & Model & R & R Square & Adjusted R Square & Std. An error of the Estimate \\
\hline & 1 & $.764^{\mathrm{a}}$ & .583 & .581 & .30000 \\
\hline a. & Predictors: (Constant), extensive training & & & \\
\hline
\end{tabular}

The R-square value indicates the moderate effect of the variable on the dependent variable in the model summary table. The results in the table above indicate that extensive training by the HR professionals is an entrepreneurship challenge faced by the food sector companies because the percentage of R-square is $58.3 \%$, due to which this variable perfectly fits the model.

Table 2: ANOVA $^{\mathrm{a}}$

\begin{tabular}{llccccc}
\hline Model & \multicolumn{1}{l}{ Sum of Squares } & df & Mean Square & $\boldsymbol{F}$ & Sig. \\
\hline \multirow{3}{*}{1} & Regression & 24.942 & 1 & 24.942 & 277.124 & $.000^{\mathrm{b}}$ \\
\cline { 2 - 6 } & Residual & 17.820 & 198 & .090 & & \\
\cline { 2 - 6 } & Total & 42.762 & 199 & & \\
\hline \multicolumn{7}{l}{ a. Dependent Variable: EntrepreneurshipChallenges } \\
\hline
\end{tabular}

The table of ANOVA is used for checking the value of $F$ and significance in a study. When the value of $F$ is greater than 1 and significance is less than 0.05 , then the hypothesis is accepted. The table above indicates that both the conditions have been (i.e., $F>1$; and significance is $<0.5$ ). The value of $F$ is 277.124 , while the significance is 0.00 . Hence, it can be summarized that extensive training by HR professionals is an entrepreneurship challenge faced by the food sector companies.

Table 3: Coefficients

\begin{tabular}{|c|c|c|c|c|c|c|}
\hline \multirow{2}{*}{\multicolumn{2}{|c|}{ Model }} & \multicolumn{2}{|c|}{ Unstandardized Coefficients } & \multirow{2}{*}{$\begin{array}{c}\begin{array}{c}\text { Standardized } \\
\text { Coefficients }\end{array} \\
\text { Beta }\end{array}$} & \multirow[t]{2}{*}{$\mathbf{t}$} & \multirow[t]{2}{*}{ Sig. } \\
\hline & & $B$ & Std. Error & & & \\
\hline \multirow{2}{*}{1} & (Constant) & .592 & .100 & & 5.952 & .000 \\
\hline & ExtensiveTraiing & .744 & .045 & .764 & 16.647 & .000 \\
\hline
\end{tabular}

The coefficients table is used for checking whether the variables are positively or negatively related to each other. The table above indicates that the value of Beta is positive and high, while the value of $t$ is also positive. Based on the observed findings, extensive training by HR professionals is an entrepreneurship challenge faced by the food sector companies by 16.647 times.

\section{Hypothesis \#2}

The second hypothesis investigated was:

H2: Written policy development by HR is an entrepreneurship challenge faced by the food sector companies.

Table 4: Model Summary

\begin{tabular}{lcccc}
\hline Model & R & R Square & $\begin{array}{c}\text { Adjusted R } \\
\text { Square }\end{array}$ & $\begin{array}{c}\text { Std. Error of the } \\
\text { Estimate }\end{array}$ \\
\hline 1 & $.508^{\mathrm{a}}$ & .258 & .254 & .40028 \\
\hline a. Predictors: (Constant), WrittenPolicy & & \\
\hline
\end{tabular}

The value of R-square is indicating the moderate effect of the variable on the dependent variable. The results in the table above indicate that written policy development by HR is an entrepreneurship challenge faced by the food sector companies because the percentage of $\mathrm{R}$-square is $25.8 \%$, due to which this variable perfectly fits the model.

Table 5: ANOVA $^{\mathrm{a}}$

\begin{tabular}{llccccc}
\hline Model & & Sum of Squares & df & Mean Square & F & Sig. \\
\hline \multirow{2}{*}{1} & Regression & 11.038 & 1 & 11.038 & 68.888 & $.000^{\mathrm{b}}$ \\
\cline { 2 - 7 } & Residual & 31.725 & 198 & .160 & & \\
\hline
\end{tabular}




\begin{tabular}{l} 
Total $42.762 \quad 199$ \\
\hline a. Dependent Variable: Entrepreneurship Challenges \\
b. Predictors: (Constant), Written Policy
\end{tabular}

The table above indicates that both the conditions have been (i.e., F>1; and significance is $<0.5$ ). The value of $\mathrm{F}$ is 68.888, while the significance is 0.00 . Hence, it can be said that written policy development by HR is an entrepreneurship challenge faced by the food sector companies.

Table 6: Coefficients

\begin{tabular}{|c|c|c|c|c|c|c|}
\hline \multirow[t]{2}{*}{ Model } & & \multicolumn{2}{|c|}{ Unstandardized Coefficients } & \multirow{2}{*}{$\begin{array}{c}\begin{array}{c}\text { Standardized } \\
\text { Coefficients }\end{array} \\
\text { Beta }\end{array}$} & \multirow[t]{2}{*}{$\mathbf{t}$} & \multirow[t]{2}{*}{ Sig. } \\
\hline & & B & Std. Error & & & \\
\hline \multirow{2}{*}{1} & (Constant) & .984 & .151 & & 6.537 & .000 \\
\hline & WrittenPolicy & .573 & .069 & .508 & 8.300 & .000 \\
\hline
\end{tabular}

The table above indicates that the value of Beta is positive and high, while the value of $t$ is also positive. Based on the observed findings, written policy development by HR is an entrepreneurship challenge faced by the food sector companies by 8.300 times.

\section{Third Hypothesis}

The third hypothesis investigated was:

H3: Induction of interaction by HR is an entrepreneurship challenge faced by the food sector companies.

Table 7: Model Summary

\begin{tabular}{|c|c|c|c|c|}
\hline Model & $\mathbf{R}$ & R Square & $\begin{array}{c}\text { Adjusted R } \\
\text { Square }\end{array}$ & $\begin{array}{l}\text { Std. Error of the } \\
\text { Estimate }\end{array}$ \\
\hline 1 & $.912^{\mathrm{a}}$ & .833 & .832 & .19015 \\
\hline
\end{tabular}

In the table, the R-square value indicates the high effect of the variable on the dependent variable. The table above indicates that HR's induction is an entrepreneurship challenge faced by the food sector companies because the percentage of R-square is $83.2 \%$, due to which this variable also perfectly fits the model.

Table 9: ANOVA $^{\mathrm{a}}$

\begin{tabular}{llccccc}
\hline Model & & Sum of Squares & df & Mean Square & F & Sig. \\
\hline \multirow{3}{*}{1} & Regression & 35.603 & 1 & 35.603 & 984.627 & $.000^{\mathrm{b}}$ \\
\cline { 2 - 7 } & Residual & 7.159 & 198 & .036 & & \\
\cline { 2 - 7 } & Total & 42.762 & 199 & & & \\
\hline
\end{tabular}

a. Dependent Variable: EntrepreneurshipChallenges

b. Predictors: (Constant), Interaction

The value of $\mathrm{F}$ is 984.627 , while significance is 0.00 ; hence, it can be summarized that induction of interaction by the HR is an entrepreneurship challenge faced by the food sector companies.

Table 10: Coefficients

\begin{tabular}{|c|c|c|c|c|c|c|}
\hline \multirow[t]{2}{*}{ Model } & & \multicolumn{2}{|c|}{ Unstandardized Coefficients } & \multirow{2}{*}{$\begin{array}{c}\begin{array}{c}\text { Standardized } \\
\text { Coefficients }\end{array} \\
\text { Beta } \\
\end{array}$} & \multirow[t]{2}{*}{$\mathbf{t}$} & \multirow[t]{2}{*}{ Sig. } \\
\hline & & B & Std. Error & & & \\
\hline \multirow{2}{*}{1} & (Constant) & .397 & .059 & & 6.685 & .000 \\
\hline & Interaction & .815 & .026 & .912 & 31.379 & .000 \\
\hline
\end{tabular}

The table above indicates that the value of Beta is positive and high, and that of $t$ is also positive. Based on the observed findings, induction of interaction by the HR is an entrepreneurship challenge faced by the food sector companies by 31.379 times.

\section{Fourth hypothesis:}

The fourth hypothesis was:

H4: Inclusion of incentives by HR is an entrepreneurship challenge faced by the food sector companies. 
Table 11: Model Summary

\begin{tabular}{lcccc}
\hline Model & R & R Square & $\begin{array}{c}\text { Adjusted R } \\
\text { Square }\end{array}$ & $\begin{array}{c}\text { Std. Error of the } \\
\text { Estimate }\end{array}$ \\
\hline $1 \quad .946^{\mathrm{a}}$ & .894 & .894 & .15099 \\
\hline a. Predictors: (Constant), Incentives \\
\hline
\end{tabular}

The value of $\mathrm{R}$-square is indicating a high effect of the variable on the dependent variable. The results in the table above indicate that the inclusion of incentives by HR is an entrepreneurship challenge faced by the food sector companies because the percentage of R-square is $89.4 \%$, due to which this variable perfectly fits the model.

Table 12: ANOVA

\begin{tabular}{lccccc}
\multicolumn{7}{c}{ ANOVA $^{\mathbf{a}}$} \\
Model & Sum of Squares & df & Mean Square & F & Sig. \\
\hline Regression & 38.248 & 1 & 38.248 & 1677.704 & $.000^{\text {b }}$ \\
\hline Residual & 4.514 & 198 & .023 & & \\
\hline Total & 42.762 & 199 & & & \\
\hline
\end{tabular}

a. Dependent Variable: Entrepreneurship Challenges

b. Predictors: (Constant), Incentives

The table above indicates that both the conditions have been (i.e., F>1; and significance is $<0.5$ ). The value of $\mathrm{F}$ is 1677.704, while the significance is 0.00 . Hence, the inclusion of incentives by HR is an entrepreneurship challenge faced by the food sector companies.

Table 13: Coefficients

Coefficients ${ }^{\mathrm{a}}$

\begin{tabular}{|c|c|c|c|c|c|c|}
\hline & \multirow[t]{2}{*}{ Model } & \multicolumn{2}{|c|}{ Unstandardized Coefficients } & \multirow{2}{*}{$\begin{array}{c}\text { StandardizedCoefficients } \\
\text { Beta } \\
\end{array}$} & \multirow[t]{2}{*}{$\mathbf{t}$} & \multirow[t]{2}{*}{ Sig. } \\
\hline & & $\mathbf{B}$ & Std. Error & & & \\
\hline \multirow{2}{*}{1} & (Constant) & .156 & .051 & & 3.036 & .003 \\
\hline & Incentives & .936 & .023 & .946 & 40.960 & .000 \\
\hline
\end{tabular}

a. Dependent Variable: Entrepreneurship Challenges

The table above indicates that the value of Beta is positive and high, with the value of $t$ being positive. The findings conclude that HR incentives are an entrepreneurship challenge faced by the food sector companies by 40.960 times.

\section{DISCUSSION}

Human resources (HR) related challenges issues affect all employers. However, due to the company's size, limited financial resources, and a smaller pool of human capital, these challenges can be more difficult for small businesses. As a result, effective human resource management is critical in today's more competitive business climate. Even businesses that have a strong understanding of human resource management face HR-related issues (Khanal, 2019; Lajqi, \& Krasniqi, 2017).

In the view of the first hypothesis, it is proved that extensive training by HR professionals is an entrepreneurship challenge faced by the food sector companies. Proper employee training may not only boost your organization's productivity but may also inspire employee engagement and loyalty. However, for small business owners, money and time may impede delivering it. Managers and other senior leaders might mentor employees. HR should implement learning and training programs for employees to assist them in making better use of their knowledge, skills, creativity, and habits. They should pay more attention to personal cleanliness habits, waste reduction, making the greatest use of the food materials offered, and meeting consumer needs (Agrawal, \& Thite, 2003; Gutierrez-Gutierrez, Barrales-Molina, \& Kaynak, 2018; Kang \& Xiong, 2021; Bisht, \& Singh, 2020). As a result, HR must develop intensive training programs to ensure that the workforce is up to date on the latest technology used in the food business.

The current study also finds positive results for the second hypothesis that written policy development by HR is an entrepreneurship challenge faced by the food sector companies. The set of written policies is the most important aspect influencing a company's growth and prosperity. Employer involvement and their attitude toward work and their organization have a significant impact on food sector companies. The food industry's human resources encounter obstacles regarding work culture, salary and wages, training and development, working hours, legal issues, and company needs. Minimum wage and longer job hours are two factors that are directly related to the food industry (Mäkitie, 2020; Alrawadieh, Karayilan, \& Cetin, 2019; Prieto, Ndinguri, Wairimu, \& Kungu, 2019; Jayadatta, 2017). Furthermore, every employee should be provided with an appropriate set of rules and regulations in the form of an employee book to avoid any issues of indiscipline or disruptiveness. 
The authors also find significant results in support of the third hypothesis that induction of interaction by HR is an entrepreneurship challenge faced by the food sector companies. Co-operation and collaboration at the managerial and operational levels reduce the gap in knowledge, expertise, and intellectual abilities, opening the door to improved organization and employment chances. HR must implement rules that foster a positive working relationship between management and employees (Kumar, Haque, \& Venugopal, 2019; Matt, \& Schaeffer, 2018; Nambisan, Wright, \& Feldman, 2019; Doh, Tashman, \& Benischke, 2019). Furthermore, it must follow a thorough decision-making system, and participation in the organization is equally respected and appreciated. The management should not delegate its responsibilities to its subordinates.

In line with the fourth hypothesis, it is proved that the inclusion of incentives by HR is an entrepreneurship challenge faced by the food sector companies. Small firms usually lack the deep "pockets" of major businesses, placing them at a competitive disadvantage regarding employee retention. The cost of benefits, taxes, training, and other expenses - which might amount to three times the employee's pay - exacerbates the situation (Guerrero, \& Urbano, 2019; Chukwudi, \& Emmanuel, 2018; Akhtar, 2021). A 401(k) plan, for example, can assist in compensating for a lesser wage. The same may be said about benefits that improve employees' work/life balance, such as flexible working hours and additional paid time off. Commuter advantages, free food, and cheap memberships to wellness programs can help fill the need. Effective human resource management, including attempts to overcome typical HR challenges, is critical because it raises the possibility of your firm recruiting and maintaining actual assets that may propel your company forward. Furthermore, it lowers the risk of noncompliance with laws and regulations, ensuring that your personnel is effectively trained to do their tasks, and guarantees that workplace problems are addressed quickly and properly

\section{CONCLUSION}

Human Resource management of the food sector companies needs to plan the business thoroughly. It majorly focuses on its staff management as they truly depend on them for their profits and revenues. Thus, being the major drivers of success, management should invest a good amount in their training, knowledge, and learning. With high skills and expertise, they can help bring in more customers to their organization, from labor management to mutual understanding, cooperative working, interaction, and communication between the managers and operational staff. The primary focus should be on sanitation to standardized operational procedures and packaging, food production, and handling, and all should be considered during the training programs. The Human Resource should well accommodate this all to minimize the challenges that can affect the company's progress and mark a recession on the economic graph. With the growing food market to acquire an upper hand, the employer-employee relationship is the most important. Determining where an organization will stand on the success scale depends on how the management treats their workers; as variants of asset or expense. Their engagement through their thoughts and decisions has a very strong influence on its goal accomplishment and sales. It is equally important for Human Resource to offer them above market-competitive salaries or marketcompetitive with additional bonuses and other incentives on their good performances and hard work towards the organization. This will create more sense of motivation to work more efficiently and professionally.

\section{LIMITATIONS AND FUTURE DIRECTIONS}

This study identifies and provides a strong gap for future studies. This study followed purposive sampling as a sampling technique; other types of sampling techniques like simple random sampling or convenient sampling can be used in future studies.

This study can also be explored by adding other HR-related entrepreneurship in the same model. Furthermore, this study was conducted in the food sector to conduct future studies in other sectors like the educational sector.

\section{AUTHOR CONTRIBUTION}

Saima Gul, Dr. Amna Ali, and Dr. Cedric Aimal Edwin contributed to writing the research and designing the article's organization. Maqsod Anwar and Zil-e-Huma Najeeb perform the statistical analyses, interpretations, and technical parts. All the author(s) have a significant contribution to the research article.

\section{ACKNOWLEDGEMENT}

We would like to thank all the independent reviewers of HSSR who conducted a feasibility study of our research work.

\section{REFERENCES}

1. Abdullah, H. (2009). Major challenges to the effective management of human resource training and development activities. Journal of International Social Research, 2(8). 11-25

2. Agrawal, N. M., \& Thite, M. (2003). Human resource issues, challenges and strategies in the Indian software industry. International Journal of Human Resources Development and Management, 3(3), $249-264$. https://doi.org/10.1504/IJHRDM.2003.003664

3. Akhtar, Z. (2021). Effect of Entrepreneurial Training for Human Resource Management of Prisoners: A Framework. International Journal of Criminal Justice Sciences, 16(1), 217-235. 
4. Akinbami, C. A. O., Olawoye, J. E., Adesina, F. A., \& Nelson, V. (2019). Exploring potential climate-related entrepreneurship opportunities and challenges for rural Nigerian women. Journal of Global Entrepreneurship Research, 9(1), 1-28. https://doi.org/10.1186/s40497-018-0141-3

5. Alrawadieh, Z., Karayilan, E., \& Cetin, G. (2019). Understanding the challenges of refugee entrepreneurship in tourism and hospitality. The Service Industries Journal, 39(9-10), 717-740. https://doi.org/10.1080/026 42069.2018.1440550

6. Atiase, V. Y., Mahmood, S., Wang, Y., \& Botchie, D. (2018). Developing entrepreneurship in Africa: investigating critical resource challenges. Journal of Small Business and Enterprise Development. https://doi.org/10.1108/JSBED-03-2017-0084

7. Banfield, P., Kay, R., \& Royles, D. (2018). Introduction to human resource management. Oxford University Press.

8. Bisht, H. S., \& Singh, D. (2020). Challenges faced by micro, small and medium enterprises: a systematic review. World Review of Science, Technology and Sustainable Development, 16(3), 205-220. https://doi.org/10. 1504/WRSTSD.2020.113046

9. Bradley, D. M., Elenis, T., Hoyer, G., Martin, D., \& Waller, J. (2017). Human capital challenges in the food and beverage service industry of Canada. Worldwide Hospitality and Tourism Themes, 9(4), 411-423. https://doi.org/10.1108/WHATT-04-2017-0017

10. Bratton, J., \& Gold, J. (2017). Human resource management: theory and practice. Palgrave. https://doi.org/10. 1057/978-1-137-58668-1

11. British Columbia Cook Articulation Committee. (2018). Human Resources in the Food Service and Hospitality Industry.

12. Chukwudi, O. M., \& Emmanuel, E. A. (2018). Challenges of human resource management in west africa underdeveloped economy. Economic and Social Development: Book of Proceedings, 560-570.

13. Delapenha, C. J., Espinosa, C., Fabre, J., Lemon, P. F., Gibson, N., \& Mujtaba, B. G. (2020). The SAS Institute's Human Resources Practices in Diversity and Inclusion. Journal of Human Resource and Sustainability Studies, 8(03), 249. https://doi.org/10.4236/jhrss.2020.83014

14. Doh, J. P., Tashman, P., \& Benischke, M. H. (2019). Adapting to grand environmental challenges through collective entrepreneurship. Academy of Management Perspectives, 33(4), 450-468. https://doi.org/10.5465 lamp.2017.0056

15. Guerrero, M., \& Urbano, D. (2019). A research agenda for entrepreneurship and innovation: the role of entrepreneurial universities. In A research agenda for entrepreneurship and innovation. Edward Elgar Publishing. https://doi.org/10.4337/9781788116015.00012

16. Gutierrez-Gutierrez, L. J., Barrales-Molina, V., \& Kaynak, H. (2018). The role of human resource-related quality management practices in new product development: A dynamic capability perspective. International Journal of Operations \& Production Management, 38(1), 43-66. https://doi.org/10.1108/IJOPM-07-2016-0387

17. Jayadatta, S. (2017). Major challenges and problems of rural entrepreneurship in India. IOSR Journal of Business and Management, 19(9), 35-44.

18. Kang, Y., \& Xiong, W. (2021). Is entrepreneurship a remedy for Chinese university graduates' unemployment under the massification of higher education? A case study of young entrepreneurs in Shenzhen. International Journal of Educational Development, 84, 102406. https://doi.org/10.1016/j.ijedudev.2021.102406

19. Khanal, K. (2019). Emerging Issues and Challenges of Women Entrepreneurship (A case study of Kathmandu Valley). Journal of Management \& Development Economics, 9(1), 61-77.

20. Kumar, N. S., Haque, M. I., \& Venugopal, K. (2019). Employment challenges in Saudi Arabia: an attitudinal study. Entrepreneurship and Sustainability Issues, 6(4), 1637-1646. https://doi.org/10.9770/jesi.2019.6.4(6)

21. Lajqi, S., \& Krasniqi, B. A. (2017). Entrepreneurial growth aspirations in challenging environment: The role of institutional quality, human and social capital. Strategic Change, 26(4), 385-401. https://doi.org/10.1002/js c.2139

22. Mäkitie, T. (2020). Corporate entrepreneurship and sustainability transitions: resource redeployment of oil and gas industry firms in floating wind power. Technology Analysis \& Strategic Management, 32(4), 474-488. https://doi.org/10.1080/09537325.2019.1668553

23. Matt, M., \& Schaeffer, V. (2018). Building entrepreneurial ecosystems conducive to student entrepreneurship: new challenges for universities. Journal of Innovation Economics Management, 1, 9-32. https://doi.org/10.391 7/jie.025.0009

24. Nambisan, S., Wright, M., \& Feldman, M. (2019). The digital transformation of innovation and entrepreneurship: Progress, challenges and key themes. Research Policy, 48(8), 103773. https://doi.org/1 0.1016/j.respol.2019.03.018

25. Pilukienè, L. (2017). Importance of motivation and work pay of young employees in the value creation chain of a business company: assessment of changes in and formation of expectations. Business, Management, and Education, 15(2), 211-226. https://doi.org/10.3846/bme.2017.375

26. Prieto, L., Ndinguri, E., Wairimu, J., \& Kungu, K. (2019, August). Promoting Rural Entrepreneurship in Kenya: A National Human Resource Development Perspective. In 5TH Biennial Conference-Nigeria 2020.

27. Stewart, G. L., \& Brown, K. G. (2019). Human resource management. John Wiley \& Sons. 
28. Taiwo, A. S., Feyisayo, K. E., \& Olamilekan, L. A. (2020). Corporate Entrepreneurship, HRM Practices, and Firm Performance. Market Forces, 15(1). 41-62.

29. Uk, N. E., \& Ukpere, W. I. (2011). Strategies to improve the level of employee motivation in the fast-food outlets in Cape Town, South Africa. African Journal of Business Management, 5(28), 11521-11531. https://doi.org/10.5897/AJBM11.1476

30. Welsh, D. H., Dragusin, M., \& Grosu, R. M. (2019). Romania's ageing population: entrepreneurship opportunities and challenges. In Handbook of research on entrepreneurship and aging. Edward Elgar Publishing. https://doi.org/10.4337/9781788116213.00022

\section{Appendices}

\section{Questionnaire}

The questionnaire developed and used in this investigation was adopted from Taiwo, Feyisayo, and Olamilekin's (2020) study. The questionnaire was segmented into different variables, which are indicated below:

Extensive training

Sufficient time is allocated for training

Sufficient money is allocated for training

Training currently provided is leading to satisfactory results

Written policy

Employees are required to sign a form indicating they have reviewed the employee handbook

The firm has a formal and written discipline policy

Written procedures and instructions are given a special importance in the firm

Interaction

During problem-solving sessions, we make an effort to discuss the team members ideas before making a decision

Supervisors encourage the people that work for them to work as a team

Supervisors encourage the people that work for them to exchange opinions and ideas

Incentives

Our incentive system encourages us to pursue firm objectives vigorously

The incentive system at this firm is fair at rewarding people who accomplish firm objectives

Our reward system really recognizes the people who contribute the most to our firm 